University of Wollongong

Research Online

Australian Institute for Innovative Materials -

Papers

Australian Institute for Innovative Materials

2005

YBCO coated conductor using biaxially textured clad composite $\mathrm{Ni}-\mathrm{Mn} / \mathrm{Ni}$ Cr substrate

D Q. Shi

University of Wollongong, dongqi@uow.edu.au

SX. Dou

University of Wollongong, shi@uow.edu.au

R. K. Ko

Korea Electrotechnology Research Institute, Korea

J K. Chung

Korea Electrotechnology Research Institute, Korea

H S. Kim

Korea Electrotechnology Research Institute, Korea

See next page for additional authors

Follow this and additional works at: https://ro.uow.edu.au/aiimpapers

Part of the Engineering Commons, and the Physical Sciences and Mathematics Commons

Research Online is the open access institutional repository for the University of Wollongong. For further information contact the UOW Library: research-pubs@uow.edu.au 


\title{
YBCO coated conductor using biaxially textured clad composite $\mathrm{Ni}-\mathrm{Mn} / \mathrm{Ni}-\mathrm{Cr}$ substrate
}

\author{
Abstract \\ A new biaxially textured composite tape of $\mathrm{Ni}-4.5 \% \mathrm{Mn} / \mathrm{Ni}-1.5 \% \mathrm{Cr}$ was used as a substrate for a YBCO \\ coated conductor through the RABiTS approach. Multi-layer $\mathrm{CeO}_{2} / \mathrm{YSZ} / \mathrm{Y}_{2} \mathrm{O}_{3}$ buffer layers and $\mathrm{YBCO}$ film \\ were deposited on the substrate by pulsed laser deposition. The deposition conditions of the buffer layers \\ and the YBCO were studied and compared. Good biaxial textures have been obtained for buffer layers on \\ composite $\mathrm{Ni}-4.5 \% \mathrm{Mn} / \mathrm{Ni}-1.5 \% \mathrm{Cr}$ substrates. Scanning electron microscopy on sample cross-sections \\ was used to examine the interface and diffusion of oxygen. The uniform formation of an $\mathrm{Ni}-\mathrm{Mn}-\mathrm{O}$ layer \\ between $\mathrm{NiO}$ and the $\mathrm{Ni}-4.5 \% \mathrm{Mn}$ layer was observed, and the $\mathrm{Ni}-\mathrm{Mn}-\mathrm{O}$ layer restricted the further \\ growth of NiO layer, which was thin and not continuous, within the coated conductor during YBCO \\ deposition at higher temperature and higher oxygen pressure. The $J_{C}$ of YBCO films on these metal \\ substrates was $1.5 \times 10^{6} \mathrm{~A} \mathrm{~cm}^{-2}$ at $77 \mathrm{~K}, 0 \mathrm{~T}$.

\section{Keywords} \\ YBCO, coated, conductor, using, biaxially, textured, clad, composite, substrate

\section{Disciplines} \\ Engineering | Physical Sciences and Mathematics

\section{Publication Details} \\ Shi, D, Dou, SX, Ko, R, Chung, J, Kim, H, Ha, H, Song, K \& Park, C (2005), YBCO coated conductor using \\ biaxially textured clad composite Ni-Mn/Ni-Cr substrate, Superconductor Science and Technology, 18, pp. \\ 1405-1409.
}

\section{Authors}

D Q. Shi, S X. Dou, R. K. Ko, J K. Chung, H S. Kim, H S. Ha, K J. Song, and C. Park 


\title{
YBCO coated conductor using biaxially textured clad composite $\mathrm{Ni}-\mathrm{Mn} / \mathrm{Ni}-\mathrm{Cr}$ substrate
}

\author{
D Q Shi ${ }^{1,4}, \mathrm{~S} \mathrm{X} \mathrm{Dou}$
K J Song \\ 1 Institute for Superconducting and Electronic Materials, University of Wollongong, Australia
${ }^{2}$ Korea Electrotechnology Research Institute, Changwon, Kyungnam, Korea
${ }^{3}$ School of Materials Science and Enginecring, Seow \\ School of Materials Science and Engineering, Seoul National University, Scoul, Korea \\ E-mail: dongqi@uow.edu.au
}

Received 16 June 2005, in final form 12 August 2005

Published 5 September 2005

Online at stacks.iop.org/SUST/18/1405

\begin{abstract}
A new biaxially textured composite tape of $\mathrm{Ni}-4.5 \% \mathrm{Mn} / \mathrm{Ni}-1.5 \% \mathrm{Cr}$ was used as a substrate for a YBCO coated conductor through the RABiTS approach. Multi-layer $\mathrm{CeO}_{2} / Y S Z / Y_{2} \mathrm{O}_{3}$ buffer layers and $\mathrm{YBCO}$ film were conditions of the buffer by pulsed laser deposition. The deposition Good biaxial textures have been the YBCO were studied and compared. $\mathrm{Ni}-4.5 \% \mathrm{Mn} / \mathrm{Ni}-1.5 \% \mathrm{Cr}$ substrates. Scanning buffer layers on composite sample cross-sections was used to examine electron microscopy on oxygen. The uniform formation examine the interface and diffusion of $\mathrm{Ni}-4.5 \% \mathrm{Mn}$ layer was observed an $\mathrm{Ni}-\mathrm{Mn}-\mathrm{O}$ layer between $\mathrm{NiO}$ and the further growth of $\mathrm{NiO}$ layer, which was thin and $\mathrm{N}$ - layer restricted the coated conductor during YBCO deposition and not continuous, within the oxygen pressure. The $J_{0}$ of $\mathrm{YBCO}$ deposition at higher temperature and higher $1.5 \times 10^{6} \mathrm{~A} \mathrm{~cm}^{-2}$ at $77 \mathrm{~K}, 0 \mathrm{~T}$.
\end{abstract}

\section{Introduction}

A high temperature superconducting (HTS) $\mathrm{YBa}_{2} \mathrm{Cu}_{3} \mathrm{O}_{7-\delta}$ (YBCO) coated conductor which consists of a superconducting deposited a buffer layer (which is multi-layer thin films) deposited on flexible metal tape is expected to satisfy the requirements of practical applications of ligh temperature nitrogen temperature obtain biaxiature. Two main methods have been used to required for highture of the superconducting layer, which is conductor. One the HTS coated mod $[1,2]$ uses ionized-beam-assisted on the polycrystalline metal first thin film layer deposited is followed by subsequetal tape biaxially textured, which ent epitaxial deposition of additional called rolling-assisted biaxially layer. The other method, uses biaxially textured

${ }^{4}$ Author to whom any correspondence should be addressed.

treatment under controlled atmosphere following mechanical deformation, and the texture of the metal tape is transferred to the buffer layer and then up to the superconducting layer through epitaxial deposition $[3,4]$. It has been shown that nickel is well suited as a substrate material for the RABiTS approach because it forms a very strong cube texture after rolling and recrystallization. In addition, it is more resistant to oxidation than e.g. copper, and the small lattice mismatch with the oxides used for buffer layers allows epitaxial growth of buffer layers and YBCO film. Current densities exceeding $10^{6} \mathrm{~A} \mathrm{~cm}^{-2}$ at $77 \mathrm{~K}$ self field have been achieved in the YBCO coated conductors made on textured $\mathrm{Ni}$ metal tape $[5,6]$. The nickel, however, has disadvantageous properties: (i) the ferromagnetism of the nickel leads to magnetization losses in ac field; (ii) its low tensile strength after heat-treatment limits the possibility of thin tapes, which are necessary to obtain a high engineering current density (i.e. the current in the HTS divided by the whole cross sectional area of the tape) [7].

One method of solving these problems is using Ni-alloy substrate instead of pure $\mathrm{Ni}[8]$. The ferromagnetic Curie 
temperature can be suppressed by alloying, which can help decrease the ac losses. The strength of the tapes is also expected to be enhanced by alloying due to solid solution hardening. Elements that can suppress the ferromagnetism of $\mathrm{Ni}$ within the solubility region are $\mathrm{V}, \mathrm{Cr}, \mathrm{Si}_{2} \mathrm{Al}, \mathrm{Ti}$ and Mo. Compared with a pure Ni substrate, $\mathrm{Ni}$ with a small amount of alloying exhibits significantly reduced ac losses and increased mechanical strength. However, for alloy substrates, in particular, $\mathrm{Ni}$ alloy substrates containing $\mathrm{Cr}$, subsequent epitaxial growth of the first oxide buffer layer is very difficult. The deposition of epitaxial oxides directly on the $\mathrm{Cr}$-containing alloy results in the formation of non-cubic $\mathrm{Cr}_{2} \mathrm{O}_{3}$. One way to get around this problem is to deposit a thin layer of $\mathrm{Ni}$ or $\mathrm{Ni}-\mathrm{W}$ on the $\mathrm{Ni}-\mathrm{Cr}$ alloy before the deposition of the first buffer layer. Another method is the design of a RABiTS clad composite substrate. These clad composite substrates were originally developed in Japan by inserting a core metal rod into a Ni pipe or by sandwiching a core metal sheet belween two Ag plates, which was followed by subsequently cold rolling and annealing as in the usual RABiTS process [9]. The core metal is usually stronger and/or has better magnetic properties in order to improve the performance without losing the biaxial texture of the original tape on the outer layer.

There are many reports on RABiTS based coated conductors that used $\mathrm{Ni}$ alloy substrates. Until recertly $\mathrm{Ni}-\mathrm{W}$ tape has been the most commonly used for replacing pure $\mathrm{Ni}$ tape in the RABiTS process [10-13]. Some studies on coated conductors based on $\mathrm{Ni}-\mathrm{Cr}$ tapes have been reported [14], and a clad composite $\mathrm{Ni}-\mathrm{Cr}$ based tape has been used forthe IBAD approach [9]. To my knowledge, there is no report about using $\mathrm{Ni}-\mathrm{Mn}$ alloy substrate for a coated conductor. Adding manganese can control grain size and suppress abrormal grain growth during recrystallization and make grains more stable at high/low temperatures. Moreover, adding manganese can increase the ductility and high strain hardening capacity of the $\mathrm{Ni-Mn}$ tape [15]. In this study, clad composite Ni$4.5 \% \mathrm{Mn} / \mathrm{Ni}-1.5 \% \mathrm{Cr}$ substrate was used as a substrate for a coated conductor through the RABiTS approach. The thermal expansion coefficients of the substrate (especially for $\mathrm{Ni}$ $1.5 \% \mathrm{Cr}$ ) can match both the buffer layers and the YBCO film within $<10 \%$. Buffer layers with the arclitecture of $\mathrm{CeO}_{2} / \mathrm{YSZ} / \mathrm{Y}_{2} \mathrm{O}_{3}$ were prepared by pulsed laser deposition (PLD). Deposition conditions, texture, microstructure and interfaces, and superconducting properties were studied.

\section{Experimental details}

PLD was used to deposit all oxide layers: $\mathrm{CeO}_{2}, \mathrm{Y}_{2} \mathrm{O}_{3}, \mathrm{YSZ}$, and $\mathrm{YBCO}$. In the PLD system, stoichiometric $\mathrm{Y}_{2} \mathrm{O}_{3}, \mathrm{YSZ}$, $\mathrm{CeO}_{2}$ and $\mathrm{YBCO}$ ceramic targets 2 inches in diameter were mounted on a multiple target carrousel, which allowed all oxide depositions for the $\mathrm{YBCO}$ coated conductor specimens to be deposited in the same chamber in situ. The background pressure of the PLD chamber was less than $10^{-6}$ Torr. Biaxially textured clad composite nickel alloy $(\mathrm{Ni}-4.5 \% \mathrm{Mn} / \mathrm{Ni}-1.5 \% \mathrm{Cr}$ ) tape was obtained from a German supplier, which has a sandwich structure with a corelayer of $\mathrm{Ni}-1.5 \% \mathrm{Cr}$ and outside Iayers consisting of $\mathrm{Ni}-4.5 \% \mathrm{Mn}$. The total thickness of the substrate is about $0.11 \mathrm{~mm}$, and the thickness of the Ni-Mn outer layer is greater than $10 \mu \mathrm{m}$.
This tape has increased mechanical strength compared to pure Ni tape. The substrates used in this investigation had biaxial textures with in-plane and out-of-plane textures evaluated by the full width at half maximum (FWHM) of the $\phi$-scan $(\Delta \phi)$ and the $\omega$-scan $(\Delta \omega)$ of $\Delta \phi=8^{\circ}-10^{\circ}$ and $\Delta \omega=8^{\circ}-9^{\circ}$ respectively. $97 \%$ of the metal tape surface area was cube textured, as evaluated by pole figures.

The substrates, with a size of about $3 \times 10 \mathrm{~mm}^{2}$, were attached with silver paste to the target holder (also the heater), which was directly facing the target. The deposition temperature was measured by a thermocouple located in the leater block. The particulars of the deposition system were the following: fixed laser beam at an angle of $60^{\circ}$ to the normal of the target; target-substrate distance $50 \mathrm{~mm}$; target rotation $25 \mathrm{rpm}$. The deposition conditions were the following: laser repetition rate $5-20 \mathrm{~Hz}$; the of the laser spot on the target $5 \times 1 \mathrm{~mm}^{2}$; puised laser energy density on the target $2-3 \mathrm{~J} \mathrm{~cm}^{-2}$. Prior to deposition, substrates were heated from room temperature to the deposition temperature of $\mathrm{Y}_{2} \mathrm{O}_{3}$ in a $200 \mathrm{mTor} \mathrm{Ar} / 4 \% \mathrm{H}_{2}$ gas mixture, to prevent oxidation of the nickel substrate. Specimens were fabricated at different stages in the $\mathrm{YBCO} / \mathrm{CeO}_{2} / \mathrm{YSZ} / \mathrm{Y}_{2} \mathrm{O}_{3} / \mathrm{Ni}$ architecture. This allowed for a study of the texture, smoothness, and microstructure of each of the deposited layers and the development of the stack.

The $\mathrm{Y}_{2} \mathrm{O}_{3}$ seed layer was deposited in 200 mTorr of $\mathrm{Ar} / 4 \% \mathrm{H}_{2}$ for $1 \mathrm{~min}$ at a $5 \mathrm{~Hz}$ laser repetition rate. Then the laser repetition rate was increased to $10 \mathrm{~Hz}$ for $4 \mathrm{~min}$. In a reducing atmosphere, the $(00 l)$ orientation of $\mathrm{X}_{2} \mathrm{O}_{3}$ can be obtained over the wide deposition temperature range of $500-750^{\circ} \mathrm{C}$, which is basically due to the good lattice match between $\mathrm{Y}_{2} \mathrm{O}_{3}$ and $\mathrm{Ni}$ (lattice mismatch about $5.7 \%$ ). After XRD $\phi$-scan and $\omega$-scan analyses, an optimal deposition temperature for the first step was chosen around $650^{\circ} \mathrm{C}$. The seducing atmosphere was removed by pumping to the base pressure of the system, which was $\sim 8 \times 10^{-6}$ Torr, and then the second part of the $\mathrm{Y}_{2} \mathrm{O}_{3}$ film was deposited. At this step, two deposition atmospheres were chosen and compared. one was $0.1 \mathrm{~m}$ Torr oxygen atmosphere, and the other was a vacuum below $8 \times 10^{-6}$ Torr which was the base pressure of the deposition system used in this study. The biaxial textures of the $y_{2} \mathrm{O}_{3}$ films deposited under these two conditions are almost the same. From the point of view of preventing the undesirable formation of an $\mathrm{NiO}$ layer between the metal substrate and the $\mathrm{Y}_{2} \mathrm{O}_{3}$ layer, it should be advantageous to deposit $\mathrm{Y}_{2} \mathrm{O}_{3}$ in high yacuum at this stage. However, after our examination of the finms, we found that the $\mathrm{NiO}$ layer and the $\mathrm{Ni}-\mathrm{Mn}-\mathrm{O}$ reaction and diffusion layers shown in the cross-section SEM image (figure 5) were not formed at this stage. The laser energy density on the target for $\mathrm{Y}_{2} \mathrm{O}_{3}$ deposition was maintained at about $2 \mathrm{~J} \mathrm{~cm}^{-2}$. After the $\mathrm{Y}_{2} \mathrm{O}_{3}$ deposition, oxygen gas was then introduced into the chamber. After stabilizing the pressure at $1 \mathrm{~m}$ Torr the temperature was then increased from 650 to $780^{\circ} \mathrm{C}$, and the YSZ buffer layer was deposited for 20 min in the current oxygen atmosphere. For the YSZ deposition, the laser energy density on the target was increased to about $3 \mathrm{~J} \mathrm{~cm}^{-2}$ and the repetition rate to $20 \mathrm{~Hz}$. Deposition times can be increased or decreased to change the thicknesses of the bayers.

A cap layer of $\mathrm{CeO}_{2}$ was deposited at the same laser energy density as for XSZ and at a repetition rate of $5 \mathrm{~Hz}$ 
YBCO coated conductor using biaxially textured clad composite $\mathrm{Ni}-\mathrm{Mn} / \mathrm{Ni}-\mathrm{Cr}$ substrate

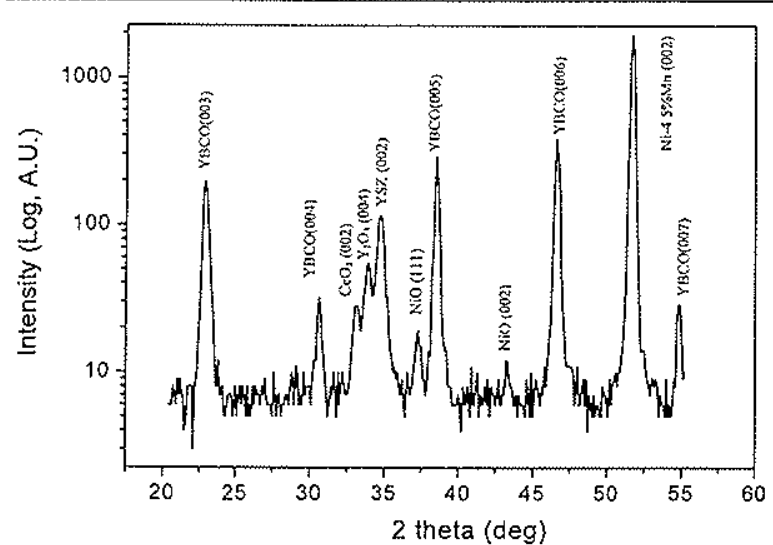

Figure 1. XRD $0-2 \theta$ scans for a typical

$\mathrm{YBCO} / \mathrm{CeO}_{2} / \mathrm{YSZ}_{2} \mathrm{Y}_{2} \mathrm{O}_{3} / \mathrm{Ni}-4.5 \% \mathrm{Mn} / \mathrm{Ni}-1.5 \%$ Cr sample.

for $2 \mathrm{~min}$. After deposition of the final buffer layer, the oxygen pressure was subsequently increased to 200 mTorr, and the superconducting YBCO layer was then deposited on the buffer layers. The YBCO film was deposited within a deposition temperature range of $770-790^{\circ} \mathrm{C}$ in 200 mTorr oxygen pressure. The laser conditions were the following: energy of $150 \mathrm{~mJ} /$ pulse and repetition rate $10 \mathrm{~Hz}$. Following deposition, the YBCO film was quickly cooled to $550^{\circ} \mathrm{C}$ under the deposition pressure, and then kept for 20 min under an oxygen pressure of 500 Torr. It is not suggested that these are the optimal conditions for PLD of the various layers, but they are the ones used in this investigation.

The as-deposited films were analysed by a variety of characterizations. To study the crystalline alignment of the substrate, buffer layers and superconductor film, XRD $\theta-2 \theta$ scans, $\omega$-scans and $\phi$-scans were made to examine the textures of samples. The microstructure of the various films was investigated by scanning electron microscopy (SEM) with surface and cross-sectional views. A Digital Instruments atomic force microscope (AFM) was used to characterize the surface morphology and roughness of the buffer layers. Electrical property characterizations of the samples were made using a standard four-probe technique with a $1 \mu \mathrm{V} \mathrm{cm}-1$ criterion to determine the critical current $\left(I_{c}\right)$ as well as the transition temperature $T_{\mathrm{c}}$. The thicknesses of the films were determined by etching the $\mathrm{YBCO}$ at an edge and measuring step height using a profilometer.

\section{Results and discussion}

To examine the epitaxial growth of the successive layers and determine the transfer of the biaxial texture of metal substrate to the films deposited on this, a series of XRD scans was taken. X-ray $\theta-2 \theta$ scans on the intermediate buffer layers of $\mathrm{YBCO} / \mathrm{CeO}_{2} / \mathrm{YSZ} / \mathrm{Y}_{2} \mathrm{O}_{3} / \mathrm{Ni}-4.5 \% \mathrm{Mn} / \mathrm{Ni}$ $1.5 \% \mathrm{Cr}$ archilecture showed sharp $(00 \mathrm{l})$ peaks indicating excellent $c$-axis texture in buffer layers that was carried over to the superconducting YBCO layer (a typical figure is shown in figure 1). However, there were very small NiO (111) and (200) peaks that were likely to form during the YBCO deposition. $\phi$-scans of the different oxide layers on the substrate indicate in-plane alignment of the various layers.

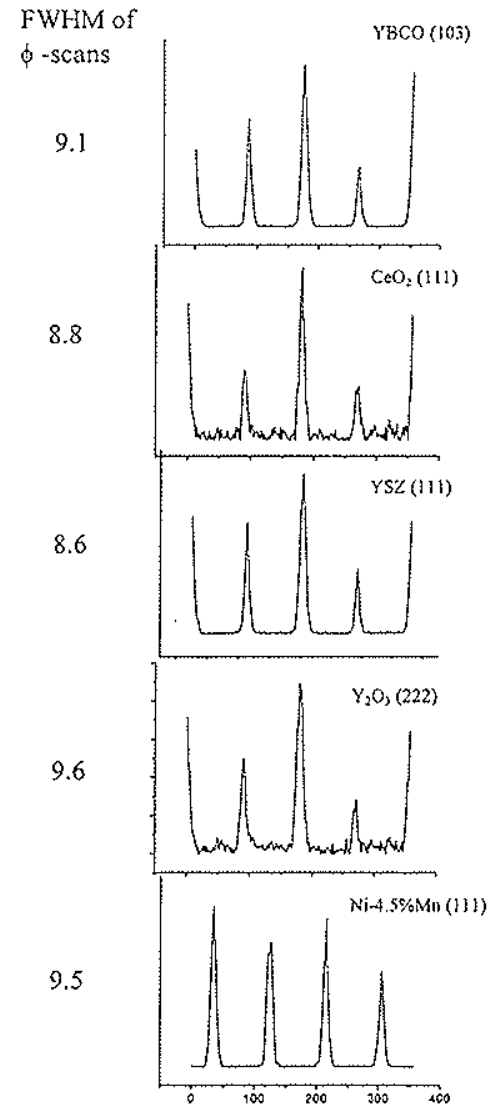

Figure 2. XRD $\phi$-scans for the typical results of a $\mathrm{YBCO} / \mathrm{CeO}_{2} / \mathrm{YSZ}_{2} \mathrm{Y}_{2} \mathrm{O}_{3} / \mathrm{Ni}-4.5 \% \mathrm{Mr} / \mathrm{Ni}-1.5 \% \mathrm{Cr}$ sample.

With a starting $\mathrm{Ni}-4.5 \% \mathrm{Mn}$ with $\Delta \phi$ of $9.5^{\circ}$, the subsequent $\triangle \phi$ are for $\mathrm{CeO}_{2}=9.6^{\circ}, \mathrm{YSZ}=8.6^{\circ}, \mathrm{CeO}_{2}=8.8^{\circ}$ and $\mathrm{YBCO}=9.1^{\circ}$ (figure 2 shows these XRD $\phi$-scans of a typical $\mathrm{YBCO} / \mathrm{CeO}_{2} / \mathrm{YSZ} / \mathrm{Y}_{2} \mathrm{O}_{3} / \mathrm{Ni}-4.5 \% \mathrm{Mn} / \mathrm{Ni}-1.5 \% \mathrm{Cr}$ sample). The role of YSZ was mainly as a barrier layer to prevent diffusion of oxygen and cation elements between YBCO and substrate. The relationship between superconducting properties of $\mathrm{YBCO}$ and the thickness of YSZ was analysed. YSZ layers were deposited with the thicknesses between 50 and $1000 \mathrm{~nm}$ at a deposition rate of about $35 \mathrm{~nm} \mathrm{~min}$ min $^{-1}$ while the thicknesses of other layers were kept constant. For this group of samples, the FWHM value of the XRD $\phi$-scan for the (111) plane of YSZ did not change much with increasing YSZ film thickness, and the average value was about $8.2^{\circ}$, indicating that the in-plane alignment was not changed by increasing the thickness of the YSZ buffer layer. The $J_{\mathrm{c}}$ of the YBCO film was increased with increasing thickness of the YSZ, and the $J_{\mathrm{c}}$ remained about $1 \mathrm{MA} \mathrm{cm}^{-2}$ once the thickness was greater than $300 \mathrm{~nm}$. Figure 3 shows the relationship between the FWHM of the $\phi$-scan, the thickness of the YSZ film and the critical current density. Figure 4 shows the $T_{c}$ and $l_{c}$ plots of a typical sample. The $I-V$ plot of the current measured in a typical specimen indicated that a $3.1 \mathrm{~mm}$ wide sample carried a critical current $\left(l_{\mathrm{c}}\right)$ of $10 \mathrm{~A}$ at liquid nitrogen temperature, which is equivalent to a $J_{c}$ of $1.5 \mathrm{MA} \mathrm{cm}^{-2}$ at $77 \mathrm{~K}$ and selffield. The $T_{\mathrm{c} 0}$ of the sample was $87.5 \mathrm{~K}$. 


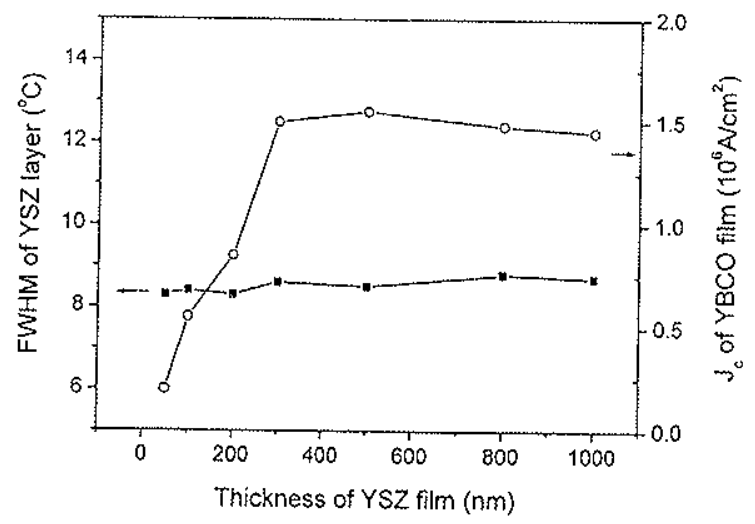

Figure 3. The relationship between the FWHM of the $\phi$-scan, the thickness of the YSZ film and the critical current density of YBCO (the thicknesses of $\mathrm{Y}_{2} \mathrm{O}_{3}, \mathrm{CeO}_{2}$ and $\mathrm{YBCO}$ were $60,2.5$, and $200 \mathrm{~nm}$, respectively).

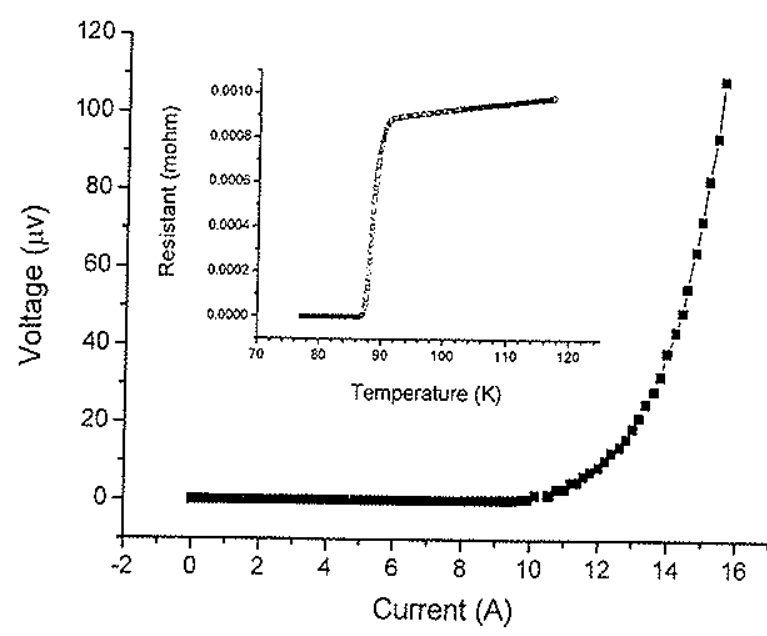

Figure 4. The $I_{\mathrm{c}}$ and $T_{\mathrm{c}}$ measurements of a typical

$\mathrm{YBCO} / \mathrm{CeO}_{2} / \mathrm{YSZ} / \mathrm{Y}_{2} \mathrm{O}_{3} / \mathrm{Ni}-4.5 \% \mathrm{Mn} / \mathrm{Ni}-\mathrm{I} .5 \% \mathrm{Cr}$ sample with the YBCO thickness $220 \mathrm{~nm}$. The width of the sample was $3.1 \mathrm{~mm}$.

Figure 5 is an SEM cross-sectional image of a $\mathrm{YBCO} / \mathrm{CeO}_{2} / \mathrm{YSZ} / \mathrm{Y}_{2} \mathrm{O}_{3}$ sample. From the image, the thicknesses of $\mathrm{Y}_{2} \mathrm{O}_{3}, \mathrm{YSZ}$, and YBCO were about 65, 290, and $130 \mathrm{~nm}$, respectively. The thickness of the $\mathrm{CeO}_{2}$ film was about $2.5 \mathrm{~nm}$ calculated by deposition rate and time. This layer cannot be seen clearly in figure 4 because it is too thin. The interfaces between $\mathrm{Y}_{2} \mathrm{O}_{3}$ and $\mathrm{YSZ}$ and also between $\mathrm{YBCO}$ and $\mathrm{CeO}_{2}$ (YSZ in the image) were clean and smooth. The $\mathrm{Y}_{2} \mathrm{O}_{3}, \mathrm{YSZ}$, and $\mathrm{YBCO}$ layers were dense from the SEM images.

The NiO layer identified by energy dispersive spectroscopy (EDS) during SEM of the cross-section, was present along the interface between the buffer and substrate. It was not uniform and not continuous. It should again be noted that NiO development within the sample occurred during the YBCO deposition process and not during the buffer layer deposition. The thickness of NiO depended on the deposition time of YBCO, e.g. the thickness of YBCO. In this image, the $Y B C O$ film is thin (about $130 \mathrm{~nm}$ ) so the NiO layer is not continuous. The layer of material between the $\mathrm{Ni}-\mathrm{Mn}$ layer and

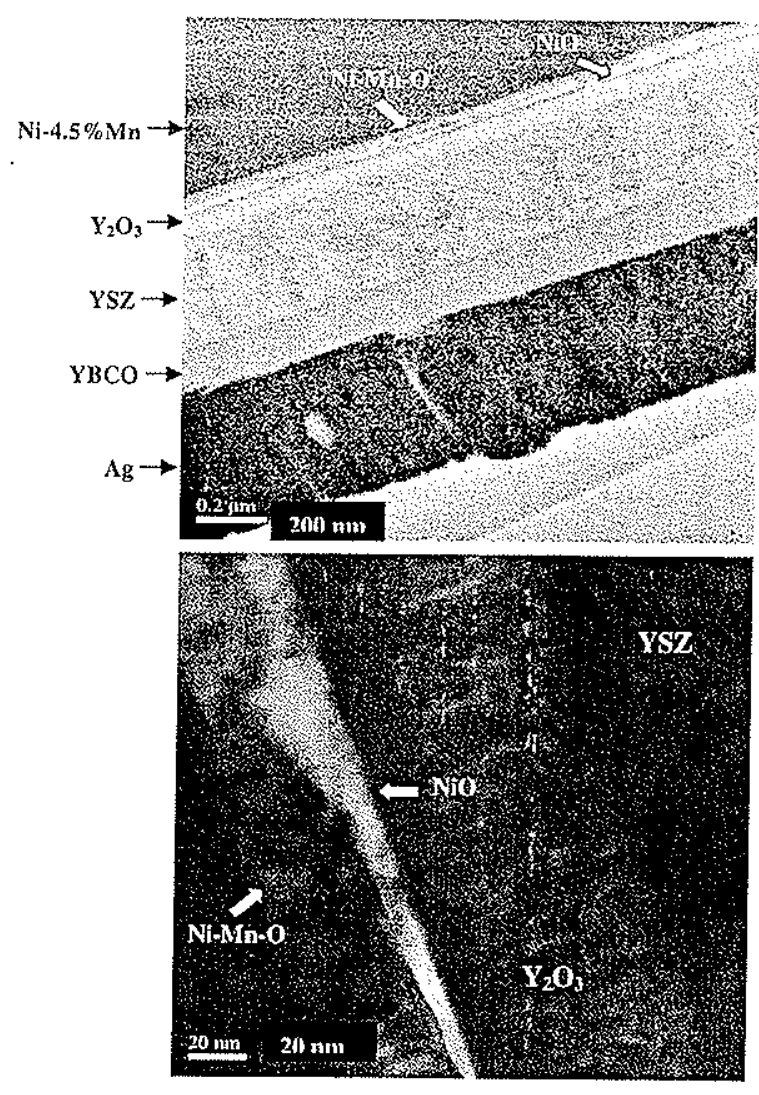

Figure 5. Cross-sectional SEM image of an $\mathrm{YBCO} / \mathrm{CeO}_{2} / \mathrm{YSZ} / \mathrm{X}_{2} \mathrm{O}_{3} / \mathrm{Ni}-4.5 \% \mathrm{Mn} / \mathrm{Ni}-1.5 \% \mathrm{Cr}$ sample.

$\mathrm{NiO}$ was identified by SEM-EDS as consisting of $\mathrm{Ni}-\mathrm{Mn}-\mathrm{O}$ species. Because this $\mathrm{Ni}-\mathrm{Mn}-\mathrm{O}$ layer is also formed during the YBCO deposition, it does not damage the texture of the buffer layers. Unlike the NiO peaks in figure 1, the XRD $\theta-2 \theta$ scan cannot show evidence of the $\mathrm{Ni}-\mathrm{Mn}$-O layer, since there may be overlap with other peaks. The reason that the Ni-MnO layer was thicker than the $\mathrm{NiO}$ layer is that elemental $\mathrm{Mn}$ is more easily oxidized than $\mathrm{Ni}$ for a given amount of $\mathrm{O}_{2}$. It is supposed that the formation of $\mathrm{Ni}-\mathrm{Mn}-\mathrm{O}$ between $\mathrm{Y}_{2} \mathrm{O}_{3}$ and the $\mathrm{Ni}-\mathrm{Mn} / \mathrm{Ni}-\mathrm{Cr}$ substrate restricted the further growth of $\mathrm{NiO}$ within the coated conductor during YBCO deposition at higher temperatures and higher oxygen pressure. Although currently being investigated, the mechanisms responsible for the development of the $\mathrm{Ni}-\mathrm{Mn}-\mathrm{O}$ layer within the substrates are not fully understood. The EDS-SEM analysis cannot give accurate quantitative measure of the elements present, and further study is under way to identify the $\mathrm{Ni}-\mathrm{Mn}-\mathrm{O}$ phase.

An AFM image of the YBCO on top of the sample is given in figure 6 . The outgrowths, or particulates on the surface, are evident here. The AFM scan on this specimen indicates that the $R_{\text {MS }}$ roughness over a $20 \mu \mathrm{m} \times 20 \mu \mathrm{m}$ area was about $57.4 \mathrm{~nm}$ including the outgrowths and was $26.7 \mathrm{~nm}$ over the same area if outgrowths are excluded. This can be compared to the roughness of the $\mathrm{CeO}_{2}$ layer, which is $R_{\mathrm{MS}}=23.6 \mathrm{~nm}$. The surface of YBCO layer is rougher than the underlying layers, which can be easily expected. 
YBCO coated conductor using biaxially textured clad composite $\mathrm{Ni}-\mathrm{Mn} / \mathrm{Ni}-\mathrm{Cr}$ substrate

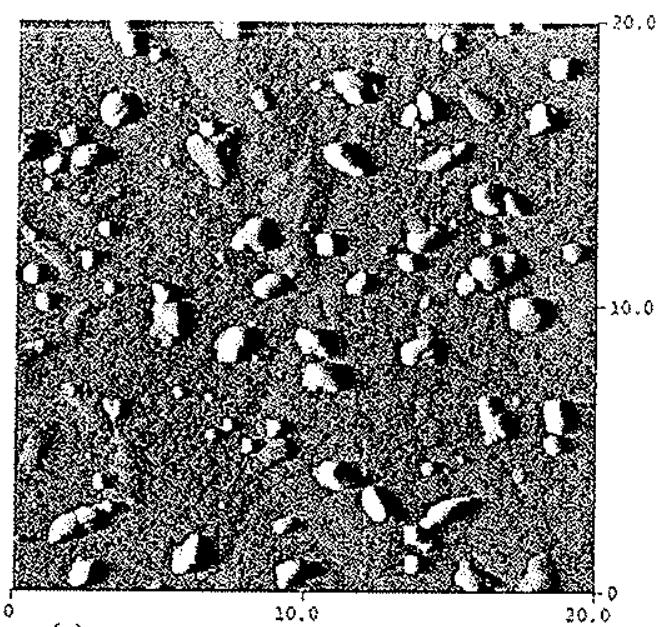

(a)

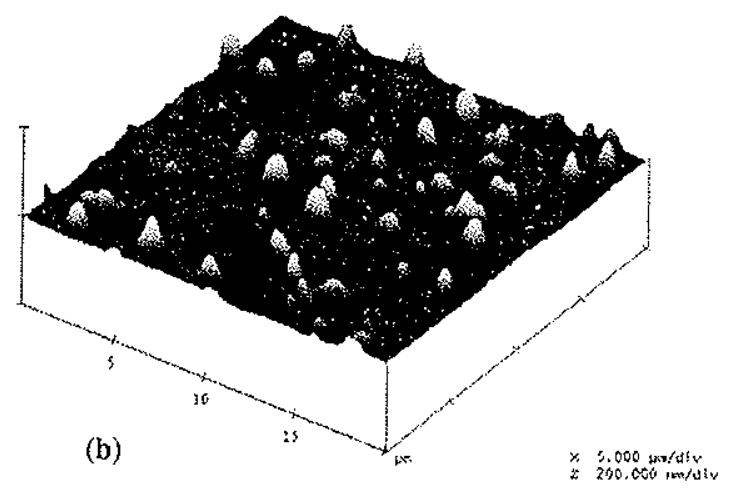

Figure 6. AFM image showing the surface morphology and roughness of the $Y B C O$ layer: (a) $2 D$ deflection image; (b) 3D height image.

\section{Conclusions}

The biaxially textured composite tape of $\mathrm{Ni}-4.5 \% \mathrm{Mn} / \mathrm{Ni}-$ $1.5 \% \mathrm{Cr}$ was used as the substrate for a coated conductor through the RABiTS approach in order to reduce the ferromagnetism and to increase the mechanical strength. Multi-layer $\mathrm{CeO}_{2} / \mathrm{YSZ} / \mathrm{Y}_{2} \mathrm{O}_{3}$ buffer layers were deposited on the substrate by pulsed laser deposition. The $\mathrm{Y}_{2} \mathrm{O}_{3}$ layer was deposited in two steps at $\mathrm{Ar} / 4 \% \mathrm{H}_{2}$ gas and vacuum in order to obtain a good biaxial texture seed layer and prevent the formation of NiO. The biaxial textures of buffer layers have been obtained on $\mathrm{Ni}-4.5 \% \mathrm{Mn} / \mathrm{Ni}-1.5 \% \mathrm{Cr}$ substrates. The thickness of the XSZ barrier layer was important to achieve a high $J_{\mathrm{c}}$ of YBCO film, and the threshold thickness was $\sim 300 \mathrm{~nm}$. Cross-sectional SEM and EDS were used to identify the presence of $\mathrm{NiO}$ and $\mathrm{Ni}-\mathrm{Mn}-\mathrm{O}$ layers at the bufferslibstrate interface. The $\mathrm{Ni}-\mathrm{Mn}-\mathrm{O}$ layer was found to form a uniform layer between $\mathrm{Y}_{2} \mathrm{O}_{3}$ and $\mathrm{Ni}-4.5 \% \mathrm{Mn}$ with thickness of $30 \mathrm{~nm}$, which was supposed to limit further $\mathrm{NiO}$ growth to between 5 and $10 \mathrm{~nm}$ in thickness. The best $J_{c}$ of YBCO films deposited by PLD on top of the $\mathrm{CeO}_{2} / \mathrm{YSZ} / \mathrm{Y}_{2} \mathrm{O}_{3} /(\mathrm{Ni}-$ $4.5 \% \mathrm{Mn} / \mathrm{Ni}-1.5 \% \mathrm{Cr}$ ) was about $1.5 \times 10^{6} \mathrm{~A} \mathrm{~cm}^{-2}$ at $77 \mathrm{~K}$ and self-field.

\section{Acknowledgments}

The samples were prepared and the $T_{c}, I_{c}$ measurements together with cross-sectional SEM images were obtained at the Korea Electrotechnology Research Institute, where the research was supported by a grant from the Center for Applied Superconductivity Technology of the 21 st Century Frontier R\&D Programme (funded by the Ministry of Science and Technology, Republic of Korea). Other measurements were oblained at the Institute for Superconducting and Electronic Materials, University of Wollongong.

\section{References}

[1] Kakimoto K, Iijima $Y$ and Saitoh T 2000 Physica C 392-396 $783-9$

[2] Wu X D, Foltyn S R, Arendt P, Townsend J, Adams C, Campbell 1 H, Tiwari P, Coulter Y and Peterson D E 1994 Appl. Phys, Lett. 651961

[3] Norton D P et al 1996 Science 274755

[4] Goyal A et al 1996 Appl. Phys. Lett. 691795

[5] Paranthaman M et al $2000 \mathrm{~J}$. Mater. Res. 152647

[6] List F A, Goyal A, Paranthaman M, Norton D P, Specht E D, Lee D F and Kroeger D M 1998 Physica C 30287

[7] Goyal A, Paranthaman M P and Schoop U 2004 MRS Bull. (August) 552

[8] Finnemore D K, Gray K E, Maley M P, Welch D O, Christen D K and Kroeger D M 1999 Physica C 320

[9] Yoshino $H_{1}$ Yamazaki $M$ and Thanh T D 2003 Physica C 392,396847

[10] Varesi E, Celentano G, Petrisor T, Boffa V, Ciontea L, Galluzzi V, Gambardella U, Mancini A, Rufoloni A and Vannozzi A 2003 Supercond. Sci. Technol. 16498

[11] Goyal A et al 2002 Physica C 382251

[12] Leonard K J, Goyal A, Kang S, Yarborough K A and Kroeger D M 2004 Supercond. Sci. Technol. 171295

[13] Shi D Q, Ko R K, Song K J, Chung J K, Ha H S, Kim H S, Moon S H, Yoo S I and Park C 2005 Supercond. Sci. Technol. 18561

[14] Ijaduola A O, Thompson J R, Goyal A, Thieme CL H and Marken K 2004 Physica C 403163

[15] de Boer B, Eickemeyer $\}$, Reger N, Fernandez G-R L, Richter I, Holzapfel B, Schultz L, Prusseit $W$ and Berberich P 2001 Acta Mater. 491421 